\title{
Lhermitte-Duclos Disease with Orthostatic Hypotension
}

\section{Ortostatik Hipotansiyon ile Birlikte İzlenen Lhermitte-Duclos Hastalı̆̆ı Olgusu}

\author{
Nesrin Helvacı Yılmaz¹, Mehmet Şeker², Mehmet Onur Omaygenç33, Umut Yaka4 , Nazan Eryiğit5', Burak Yuluğ ${ }^{1}$ \\ ${ }^{1}$ Medipol University Faculty of Medicine, Department of Neurology, İstanbul, Turkey \\ 2Medipol University Faculty of Medicine, Department of Radiology, İstanbul, Turkey \\ ${ }^{3}$ Medipol University Faculty of Medicine, Department of Cardiology, İstanbul, Turkey \\ ${ }^{4}$ Medipol University Faculty of Medicine, Department of Neurosurgery, İstanbul, Turkey \\ ${ }^{5}$ Çakmak Erdem Hospital, Clinic of Neurosurgery, İstanbul, Turkey
}

\section{Summary}

Lhermitte-Duclos disease is a rare cerebellar dysplastic gangliocytoma. The most common symptoms include headache, nausea, vomiting, blurred vision, and imbalance. The typical appearance on cranial magnetic resonance imaging is hyper-intensity on T2-weighted images and hypo-intensity on T1-weighted images. The disease generally presents with benign progress. Development of obstructive hydrocephalus is an indication for urgent surgical intervention and surgery outcomes are satisfactory. Orthostatic hypotension is a very rare clinical presentation of this syndrome and ours is the second case of orthostatic hypotension to be reported in the literature.

Keywords: Lhermitte-Duclos disease, orthostatic hypotension, cerebellum

$\ddot{\mathbf{O z}}$

Lhermitte-Duclos hastalığı serebellumun nadir görülen displastik ganliyositomuna verilen isimdir. En sık başvuru şikayetleri baş ağrısı, bulant1, kusma, dengesizlik ve görme bulanıklığıdır. Tanıda kranyal manyetik rezonans görüntülemede T2 ağırlıklı kesitlerde hiperintens, T1 ağırlıklı kesitlerde hipointens görünüm oldukça tipiktir. Sıklıkla iyi seyirlidir. Obstrüktif hidrosefali gelişimi acil cerrahi müdahale endikasyonudur ve sonuç yüz güldürücüdür. Ortostatik hipotansiyon bu sendromun çok nadir görülen klinik prezentasyonu olup bizim hastamız literatürde bildirilen ikinci olgudur.

Anahtar Kelimeler: Lhermitte-Duclos hastalı̆̆ı, ortostatik hipotansiyon, serebellum

\section{Introduction}

Dysplastic gangliocytoma of the cerebellum, also known as Lhermitte-Duclos disease (LDD), is a rare hamartomatous disorder of the cerebellar cortex $(1,2)$. It typically presents in young adults but can also appear at all ages (3). It is known as a slowly progressive and benign disease but rarely it can cause obstructive hydrocephalus and careful follow-up is required. We report a patient with LDD who was admitted to hospital with sudden and short-term loss of consciousness.

\section{Case Report}

A woman aged 21 years was presented to our neurology clinic reporting a sudden loss of consciousness lasting a few seconds, which happened two weeks before admission. Her parents reported no convulsions or urinary incontinence. She had reported

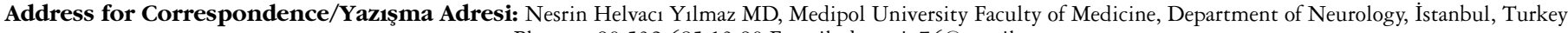
Phone: +90 5326851390 E-mail: drnesrin76@gmail.com

Received/Geliş Tarihi: 27.02 .2015 Accepted/Kabul Tarihi: 27.04 .2015

(c) Turkish Journal of Neurology, Published by Galenos Publishing House.

This article is distributed under the terms of the "Creative Commons Attribution NonCommercial 4.0 International Licence (CC BY-NC 4.0)".
} 
sudden blackouts of vision for a few years. In her medical history she had had breath holding spells once per month when she was between 11 months and 3 years of age. She had not taken any drugs in that period. Her neurologic examination was normal. Total blood count, liver, kidney and thyroid function tests, serum levels of glucose, calcium, magnesium and vitamin B12, which were performed for the differential diagnosis of syncope, were normal. An awake electroencephalograph was performed for thirty minutes and was normal. Her cardiologic examination, electrocardiography, echocardiography and rhythm Holter tests were normal. During the tilt table test, at the tenth minute after provocation she had a spell of syncope and was diagnosed as having orthostatic hypotension. Cranial magnetic resonance imaging (MRI) showed dysplastic gangliocytoma of the left cerebellum (Figure 1,2). Cranial MR angiography, and carotid and vertebral artery Doppler ultrasonography were normal. Physicians from the department of neurosurgery did not consider a surgical operation.

\section{Discussion}

Gangliocytomas are benign intraparenchymal tumors composed of neoplastic ganglion cells and stromal glial cells (4). The pathologic changes in gangliocytoma of the cerebellum that cause LDD are the loss of the middle Purkinje cell layer and infiltration of the internal granular cell layer with large neurons with vesicular nuclei and marked nucleoli, which enlarge cerebellar folias $(1,5)$. Findings of light and electron microscopes show that these cells are hypertrophic granular cells (2).

The most common symptoms of LDD are headache, nausea, vomiting, dizziness, imbalance, and blurred vision (6). Papilledema, cranial nerve palsies, ataxia, and confusion can be found in the neurologic examination $(1,3)$. Neuroimaging is enough to make the diagnosis (7). Cerebellar enlargement causes a typical striated pattern that can be seen as hyper-intense in T2- and hypo-intense in T1-weighted sequences of cranial MRI (8).

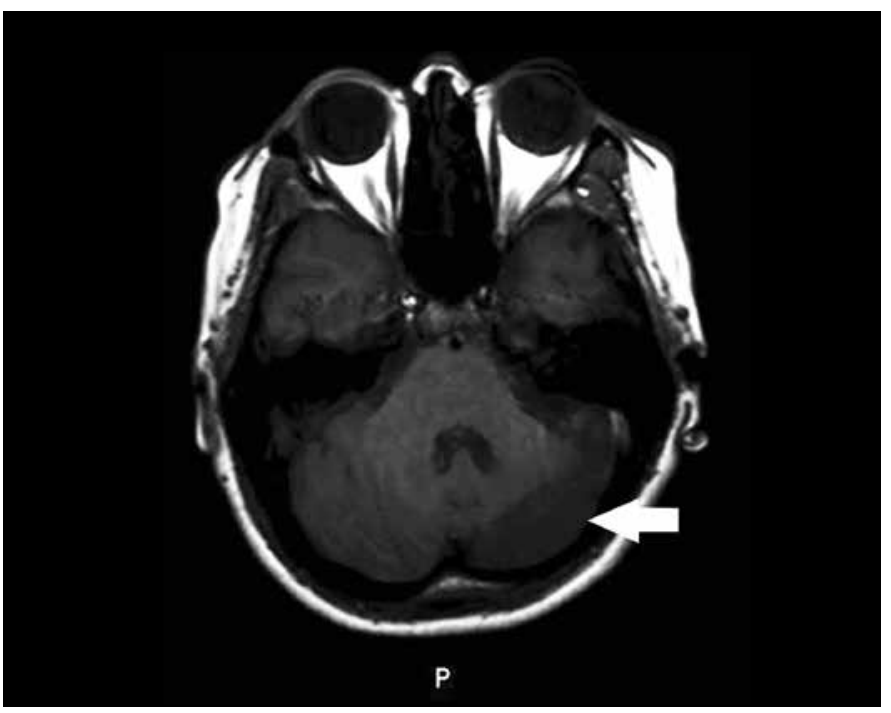

Figure 1. T1 hypointensity in the left posterior inferior cerebellar hemisphere in axial magnetic resonance imaging
These tumors are slowly progressive and some patients can be asymptomatic (9). It can take a couple of months to ten years to manifest $(10,11)$. However, the treatment options are controversial; observation, performing biopsy, or resection $(10,11)$. Sudden onset headache, vomiting, and findings of hydrocephalus are indications for surgery (12). The results of surgery are satisfactory but recurrence can be seen (13).

Cowden sydrome (autosomal dominant inherited multiple hamartoma syndrome) should be kept in mind in patients with LDD (14). LDD is one of the major diagnostic criteria for Cowden syndrome and these patients should be scanned for phosphatase and tensin homolog gene mutations and cancers (15). Our patient had no skin lesions or history of cancer.

Orthostatic hypotension is more common in elder patients but it can also accompany neurologic disorders including multisystem atrophy, Lewy body dementia, Parkinson's disease, amyloidosis, and diabetic autonomic neuropathy (16). Orthostatic hypotension has also been reported with posterior fossa lesions, including medullary tumors and infarctions $(17,18)$. In our patient, who was admitted with sudden and short-term loss of consciousness and had normal neurologic examination, we considered that the concurrence of syncope and tumor could have been a conincidence, but when we searched the literature we found a patient with orthostatic hypotension who had completely recovered after resection of tumor (5). In our case, despite the lack of medullary involvement, the most important clinical finding was orthostatic hypotension. The increase in intracranial pressure is suggested to indirectly cause orthostatic hypotension.

\section{Conclusion}

LDD is a very rare disorder and our patient is only the second reported in the literature. To explain the relationship between brain stem and spells of orthostatic hypotension, we suggest fluorodeoxyglucose-positron emission tomograhy studies should be performed.

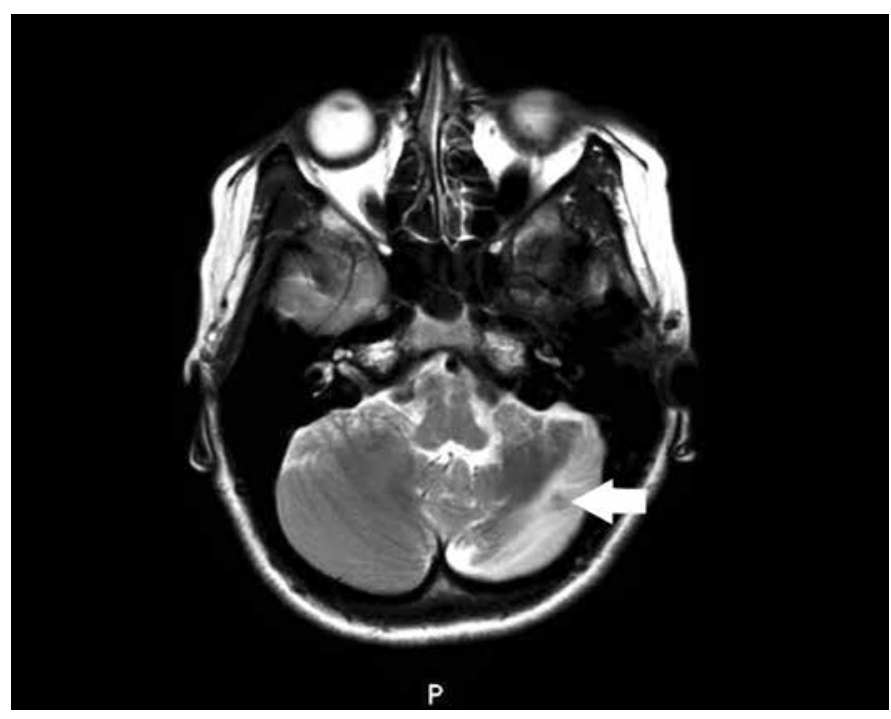

Figure 2. T2 hyperintensity in the left posterior inferior cerebellar hemisphere in axial magnetic resonance imaging 


\section{Ethics}

Informed Consent: Consent form was filled out by all participants, Peer-review: External and internal peer-reviewed.

\section{Autborship Contributions}

Surgical and Medical Practices: Nesrin Helvacı Yılmaz, Umut Yaka, Nazan Eryiğit, Mebmet Onur Omaygenç, Concept: Nesrin Helvacı

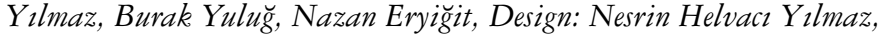
Mebmet Seker, Burak Yuluğ, Data Collection or Processing: Nesrin Helvacı Yılmaz, Mehmet Seker, Analysis or Interpretation: Nesrin Helvacı Yılmaz, Mehmet Şeker, Mehmet Onur Omaygenç, Literature Search: Nesrin Helvacı Yılmaz, Mebmet Onur Omaygenç, Burak Yulŭg, Writing: Nesrin Helvacı Yılmaz, Burak Yuluğ.

Conflict of Interest: No conflict of interest was declared by the authors. Financial Disclosure: The authors declared that this study has received no financial support.

\section{References}

1. Nowak DA, Trost HA, Porr A, Stölzle A, Lumenta CB. Lhermitte-Duclos disease (Dysplastic gangliocytoma of the cerebellum). Clin Neurol Neurosurg 2001;103:105-110.

2. Onder E, Arikök AT, Türkoğlu E, Alper M. Lhermitte-Duclos Disease: A Rare Lesion with Variable Presentations and Obscure Histopathology. Turk Patoloji Derg 2014.

3. Nowak DA, Trost HA. Lhermitte-Duclos disease (dysplastic cerebellar gangliocytoma): a malformation, hamartoma or neoplasm? Acta Neurol Scand 2002;105:137-145.

4. Türeyen K, Senol N, Sav A. Gangliocytoma associated with focal cortical dysplasia in a young-adult: a case report. Turk Neurosurg 2008;18:259-263.

5. Ruchoux MM, Gray F, Gherardi R, Schaeffer A, Comoy J, Poirier J Orthostatic hypotension from a cerebellar gangliocytoma (Lhermitte-Duclos disease). Case report J Neurosurg 1986;65:245-248.
6. Wei G, Zhang W, Li Q, Kang X, Zhao H, Liu X, Tang X, Wu Y, Han J, Yin H Magnetic resonance characteristics of adult-onset Lhermitte-Duclos disease: An indicator for active cancer surveillance? Mol Clin Oncol 2014;2:415-420.

7. Shinagare AB, Patil NK, Sorte SZ. Case 144: Dysplastic cerebellar gangliocytoma (Lhermitte-Duclos disease). Radiology 2009;251:298-303.

8. Meltzer CC, Smirniotopoulos JG, Jones RV. The striated cerebellum: an MR imaging sign in Lhermitte-Duclos disease (dysplastic gangliocytoma). Radiology 1995;194:699-703.

9. Giorgianni A, Pellegrino C, De Benedictis A, Mercuri A, Baruzzi F, Minotto R, Tabano A, Balbi S. Lhermitte-Duclos disease. A case report Neuroradiol J 2013;26:655-660.

10. Milbouw G, Born JD, Martin D, Collignon J, Hans P, Reznik M, Bonnal $\mathrm{J}$. Clinical and radiological aspects of dysplastic gangliocytoma (LhermitteDuclos disease): a report of two cases with review of the literature. Neurosurgery 1988;22:124-128.

11. Capone Mori A, Hoeltzenbein M, Poetsch M, Schneider JF, Brandner S, Boltshauser E. Lhermitte-Duclos disease in 3 children: A clinical long-term observation. Neuropediatrics 2003;34:30-35.

12. Bozbuga M, Gulec I, Suslu HT, Bayindir C. Bilateral Lhermitte-Duclos disease. Neurol India 2010;58:309-311.

13. Hashimoto H, Iida J, Masui K, Nishi N, Sakaki T. Recurrent LhermitteDuclos disease: Case report. Neurol Med Chir [Tokyo] 1997;37:692696.

14. Riegert-Johnson DL, Gleeson FC, Roberts M, Tholen K, Youngborg L, Bullock M, Boardman LA. Cancer and Lhermitte-Duclos disease are common in Cowden syndrome patients. Hered Cancer Clin Pract 2010;8:6.

15. Pilarski R, Burt R, Kohlman W, Pho L, Shannon KM, Swisher E. Cowden syndrome and the PTEN hamartoma tumor syndrome: systematic review and revised diagnostic criteria. J Natl Cancer Inst 2013;105:1607-1616.

16. Maule S, Papotti G, Naso D, Magnino C, Testa E, Veglio F. Orthostatic hypotension: evaluation and treatment. Cardiovasc Hematol Disord Drug Targets 2007;7:63-70

17. O'Malley WE, O'Doherty DS, Auth TL. Orthostatic hypotension as a manifestation of posterior fossa tumor. Dis Nerv Syst 1970;31:846-850.

18. Korpelainen JT, Sotaniemi KA, Suominen K, Tolonen U, Myllylä VV. Cardiovascular autonomic reflexes in brain infarction. Stroke 1994;25:787792. 